\title{
Snag characteristics and dynamics following natural and artificially induced mortality in a managed loblolly pine forest
}

\author{
Stanley J. Zarnoch, Mark A. Vukovich, John C. Kilgo, and John I. Blake
}

\begin{abstract}
A 14-year study of snag characteristics was established in 41- to 44-year-old loblolly pine (Pinus taeda L.) stands in southeastern USA. During the initial 5.5 years, no stand manipulation or unusually high-mortality events occurred. Afterwards, three treatments were applied consisting of trees thinned and removed, trees felled and not removed, and artificial creation of snags produced by girdling and herbicide injection. The thinned treatments were designed to maintain the same live canopy density as the snag-created treatment, disregarding snags that remained standing. We monitored snag height, diameter, density, volume, and bark percentage; the number of cavities was monitored in natural snags only. During the first 5.5 years, recruitment and loss rates were stable, resulting in a stable snag population. Large snags ( $\geq 25 \mathrm{~cm}$ diameter) were common, but subcanopy small snags (10 to $<25 \mathrm{~cm}$ diameter) dominated numerically. Large natural snags survived (90\% quantile) significantly longer (6.0-9.4 years) than smaller snags (4.4-6.9 years). Large artificial snags persisted the longest (11.8 years). Cavities in natural snags developed within 3 years following tree death. The mean number of cavities per snag was five times greater in large versus small snags and large snags were more likely to have multiple cavities, emphasizing the importance of mature pine stands for cavity-dependent wildlife species.
\end{abstract}

Résumé : Une étude d'une durée de 14 ans portant sur les caractéristiques des chicots a été établie dans des peuplements de pin à encens (Pinus taeda L.) dans le sud-est des États-Unis. Durant les 5,5 premières années, il n'y a eu aucune intervention ni épisode de mortalité inhabituellement élevée. Par la suite, trois traitements ont été appliqués : éclaircie avec enlèvement des arbres abattus; abattage d'arbres laissés sur place; et création artificielle de chicots par annélation et injection d'herbicide. Les éclaircies ont été planifiées de manière à conserver la même densité de couvert forestier vivant que le traitement de création de chicots en ne tenant pas compte des chicots qui sont demeurés debout. Nous avons effectué un suivi de la hauteur, de la densité et du volume des chicots ainsi que du pourcentage d'écorce sur les chicots; le nombre de cavités a été relevé sur les chicots naturels seulement. Pendant les 5,5 premières années, les taux de recrutement et de perte sont demeurés stables, d'où une population stable de chicots. Les gros chicots (diamètre $\geq 25 \mathrm{~cm}$ ) étaient communs mais les petits chicots (diamètre $=10$ à $<25 \mathrm{~cm}$ ) en sous-étage dominaient en nombre. Les gros chicots naturels ont survécu (quantile 90\%) significativement plus longtemps (6,0-9,4 ans) que les chicots plus petits (4,4-6,9 ans). Les gros chicots artificiels ont persisté le plus longtemps (11,8 ans). Des cavités se sont formées dans les chicots naturels moins de trois ans après la mort des arbres. Le nombre moyen de cavités par chicot était cinq fois plus élevé sur les gros chicots que sur les petits et les gros chicots était plus susceptibles d'avoir plus d'une cavité, faisant ressortir l'importance des pinèdes matures pour les espèces sauvages dont le sort est lié à la présence de cavités. [Traduit par la Rédaction]

\section{Introduction}

Snag recruitment and loss are key processes in regulating the quantity of coarse woody debris (McMinn and Crossley 1996). Snags themselves are an important resource for many wildlife species (Davis et al. 1983). However, complex interactions between vegetation structure and ecological processes such as predation, competition, and foraging appear to preclude simple relationships between snag density and species abundance in nonmanaged forest landscapes at least for avian species for which much of the research on snags has been performed (Wiebe 2011). Nevertheless, evidence exists that in managed forests, snags and associated cavity resources can limit occurrence or density of some cavitynesting species (Homyack et al. 2011).

Forest management practices can affect snag density, snag species, and other snag characteristics (Land et al. 1989). Snag size is influenced by forest age (Ohmann et al. 1994), and the number of snags can be affected by thinning (Hagar et al. 1996). Although management is typically believed to limit snag resources, it can also increase them through actions such as prescribed fire
(Sullivan et al. 2003), establishment of high stem densities that leads to density-dependent tree mortality (Garber et al. 2005), and thinning that induces root disease mortality (Barnard 1999).

The influence of the wide variety of management activities on snag attributes (density, species, and dynamics) has important implications for conservation (McMinn and Crossley 1996). The southern USA region is characterized by high snag-decay rates (disintegration of wood) that result in a rapid loss (falling) of snags that become down woody debris (Conner and Saenz 2005) compared with more northern temperate forests (Garber et al. 2005, Dunn and Bailey 2012). Following tree death, Moorman et al. (1999) observed a 95\% loss of pine snags in 6 years and Conner and Saenz (2005) observed a 90\% loss of large pine snags in 10 years. Both Moorman et al. (1999) and Radtke et al. (2009) reported that diameter at breast height $(1.37 \mathrm{~m}$; DBH) did not affect loss rate.

In 1995 a large-scale 14-year experiment was installed in 41- to 44-year-old loblolly pine (Pinus taeda L.) stands to test the impact of levels of coarse woody debris, both down logs and snags, on selected vertebrate and invertebrate populations (McCay et al. 2002). In conjunction with this study, we determined annual stocks as

Received 8 November 2012. Accepted 7 June 2013.

S.J. Zarnoch. USDA Forest Service, Clemson, SC 29634, USA.

M.A. Vukovich, J.C. Kilgo, and J.I. Blake. USDA Forest Service, New Ellenton, SC 29809, USA.

Corresponding author: Stanley J. Zarnoch (e-mail: szarnoch@fs.fed.us). 
well as recruitment and loss rates for snags in stands subject to thinning and burning, along with experimental treatments including artificial creation of snags by killing trees with girdling and herbicide injection. We examined snag dynamics of annual cohorts and tested the relationship between snag survival and snag age, size, and treatment, including cause of death (natural versus artificial). Our objective was to test the following hypotheses. First, based upon previous studies in the region (Moorman et al. 1999; Radtke et al. 2009), we expected that loss rates would be independent of snag diameter (diameter at breast height, DBH) and would fall within the range of previous studies. Second, loss rates would be unaffected by thinning and felling practices, or artificial snag creation. Our null hypothesis reflects the limited evidence for these effects in the southern forest (Homyack et al. (2011). Third, that cavity occurrence would increase with DBH (Rosenberg et al. 1988; Sabin 1991) and snag age as a result of decay conditions (Cain 1996).

\section{Methods}

We conducted the study at the US Department of Energy's Savannah River Site (SRS), an 80 000-ha National Environmental Research Park in Aiken and Barnwell counties, South Carolina (Kilgo and Blake 2005), in the Upper Coastal Plain and Sandhills physiographic provinces.

\section{Experimental design}

We installed the study in four large loblolly pine stands that were established on old fields between 1951 and 1953 when the SRS conducted a major reforestation program. The soils are predominately loamy to fine-loamy, kaolinitic, thermic arenic plinthic kandiudults in the US taxonomic classification. Our study was a subset of a multidisciplinary experiment and was established in three 9.1-ha plots in each of the four stands beginning in December 1995-January 1996 . These stands were operationally thinned 1-5 years prior to study establishment. Stocking levels in recently thinned stands of this age class at SRS are typically 18$20 \mathrm{~m}^{2} \cdot \mathrm{ha}^{-1}$ of basal area (BA). Prescribed burning was performed on these stands within three years prior to study initiation, and subsequently in early 2000 (3 stands), early 2001 (1 stand), and finally in spring 2004 (3 stands).

The study spanned a 5.5-year pre-snag treatment period (pretreatment; 1996 to early-2001) and an 8.5-year post-snag treatment period (post-treatment; mid-2001 to 2009). We used a randomized block design where one plot in each of the four stands (blocks) was randomly assigned to one of three treatments as follows: standing woody debris (SWD), down woody debris (DWD), and control (CON). In the pretreatment period, all three treatments received no stand manipulation and were effectively identical except that in the DWD treatment all down woody debris was cut with power saws, placed in a trailer, and removed by a small farm tractor, which was required to meet another objective of this study.

At the beginning of the post-treatment period we implemented catastrophic pulse treatments in March-April 2001. Our goal was to increase snag BA levels on SWD by about 10-fold above that observed during the pretreatment period in CON and SWD treatments, which averaged approximately $0.50 \mathrm{~m}^{2} \cdot \mathrm{ha}^{-1}$ in 1999 . In every plot we designated approximately $5 \mathrm{~m}^{2} \cdot \mathrm{ha}^{-1} \mathrm{BA}$ for application of one of the three treatments by marking all live trees in 12 evenly spaced, $3.75-\mathrm{m}$ wide parallel strips. Depending on the treatment assigned to each plot, these trees were then either thinned and removed (CON), felled with only tops removed (DWD), or killed by mechanical girdling and herbicide injection (SWD). These post-treatments affected an average of $22 \%$ of the live BA in the plots, which averaged $20.1 \mathrm{~m}^{2} \cdot \mathrm{ha}^{-1}$ just prior to treatment. The CON plots were thinned to maintain the same level of canopy disturbance as on SWD and DWD. The DWD treatment was identical to the $\mathrm{CON}$ in all respects related to snag management, and differed only in regard to the addition of downed logs during post-treatment. We created snags in SWD by double chain saw girdles at $1 \mathrm{~m}$ aboveground, followed by injection of Pathway $(5.4 \%$ picloram and $20.9 \%$ 2,4-D-amine) diluted in water into the girdled area. Many of these injected trees died in the first 6-8 months, but we re-treated trees that showed evidence of slow crown death in November 2001. We felled trees for the DWD treatment using chain saws during August 2001 and thinned trees for the CON treatment during August-October 2001 using a feller-buncher and skidded the material off the plots.

\section{Monitoring}

Within each 9.1-ha plot we established sixteen $50 \mathrm{~m} \times 50 \mathrm{~m}$ subplots (four rows of four subplots each) in the central 4 ha. During pretreatment through the first post-treatment measurement in December 2001, we monitored all 16 subplots. However, the large amount of material generated by SWD and DWD during post-treatment compelled us to reduce monitoring to eight and six randomly selected subplots per plot on those treatments, respectively, although we continued to monitor all 16 subplots on CON. Pretreatment measurements were initially conducted in January-February 1996 and, subsequently, during summer (MayAugust), except in 2001 when we monitored in January-February just prior to application of the treatments. We made a measurement in December 2001 (designated as 2001.9) on all subplots to characterize the immediate impact of the treatments. We continued post-treatment monitoring during the winter (JanuaryMarch) of 2003 through 2008. During 2009, we monitored only CON and SWD treatments.

In 1997 we began tagging all snags $(\geq 10 \mathrm{~cm}$ in $\mathrm{DBH})$ with a unique number at the time of first occurrence to maintain individual snag identity. A total of 724 and 2024 unique snags were monitored during the pretreatment and post-treatment periods, respectively. We measured annually the following characteristics of each snag $\geq 2 \mathrm{~m}$ tall: species group (pine or hardwood), height (HT), DBH outside bark, height to $10 \mathrm{~cm}$ diameter or height to the snag break point if the snag broke below the $10 \mathrm{~cm}$ diameter point on the bole (HT10), and estimated diameter outside bark (DOB) at HT10. For snags $<2 \mathrm{~m}$ tall, we measured HT10 and midpoint diameter $(D)$ between the ground and HT10. We estimated percentage of bark remaining on the surface of every snag in $10 \%$ intervals. We recorded the number of cavities in every snag during 19972001.9 only.

The calculation of snag volume in cubic meters $\left(\mathrm{m}^{3}\right)$ outside bark from the ground to HT10 depended on whether the snag was $<2 \mathrm{~m}\left(V_{\mathrm{S}}\right)$ or $\geq 2 \mathrm{~m}\left(V_{\mathrm{L}}\right)$. We calculated $V_{\mathrm{S}}$ as

$$
V_{\mathrm{S}}=3.14\left[\frac{D}{2(100)}\right]^{2} \mathrm{HT} 10
$$

For snags $\geq 2 \mathrm{~m}$, we based volume on a frustum of a cone. We computed the ground diameter outside bark $(G)$ as

$$
G=\mathrm{DBH}+1.37\left(\frac{\mathrm{DBH}-\mathrm{DOB}}{\mathrm{HT} 10-1.37}\right)
$$

We then calculated volume outside bark as

$$
V_{\mathrm{L}}=3.14\left[\frac{\left(\frac{\mathrm{DOB}+G}{2}\right)}{2(100)}\right]^{2} \text { HT10 }
$$

\section{Statistical analysis}

We compared plot-level snag density (number $\cdot$ ha $^{-1}$ ) and volume $\left(\mathrm{m}^{3} \cdot \mathrm{ha}^{-1}\right)$ among treatments separately for each time period. We further subdivided response variables by snag size, defining small snags as $<25 \mathrm{~cm} \mathrm{DBH}$ and large snags as $\geq 25 \mathrm{~cm}$ DBH at their initial measurement. This break point characterizes pine stands 
grown on old-field sites, which typically have a two-age structure associated with succession and understory tree regeneration following thinning disturbances (Fig. 1a). This break point carried over to the post-treatment period and, despite the treatments, it captures the relatively distinct distribution of the small snag and large snag classes (Fig. 1b). We combined both pine and hardwood snags within each DBH class. Pines were $37 \%$ and $75 \%$ of the small snag observations during pretreatment and post-treatment, respectively, and $96 \%$ and $97 \%$ of the large snags.

We used a randomized-block, repeated-measures design with blocks as the random factor, treatments as the fixed factor, and year as the repeated measures factor (Littell et al. 2006). We used PROC MIXED for the analysis, and tested several covariance structures (variance components, autoregressive, compound symmetry, unstructured, and Huynh-Feldt) with the denominator degrees of freedom option ddfm=kenwardroger (SAS Institute Inc. 2004). The autoregressive with a one-year lag covariance structure performed the best according to Akaike's information criterion corrected and was used for all repeated measures analyses. If interaction was not significant but either or both main effects were, we used the Tukey-Kramer multiple comparison procedure at the $\alpha=0.05$ type I error level to separate least-squares means within any significant factor. When interaction was significant, we obtained treatment-year least-squares means and performed slice option F tests, which, if significant, were followed by all pairwise treatment comparisons within each year, controlling the type I experimentwise error at 0.05 for the three comparisons within each year by using the Bonferroni-corrected $\alpha$ of $0.05 / 3=0.0167$. Most variables satisfied the normality and homogeneity of variance assumptions. We evaluated conformance to normality mainly with estimates of skewness and kurtosis and histogram plots of residuals. We inspected homogeneity of variances with plots of residuals versus predicted and versus treatments, and with comparisons of estimates of variance among treatments. We also performed formal tests for normality (Shapiro-Wilk, Kolmogorov-Smirnov, Anderson-Darling, Cramer - von Mises) and homogeneity of variance (Brown-Forsythe, Levine, Obrien, and Bartlett), but since they were sensitive to sample size and, thus, gave mixed results, we did not rely on them as the main criteria for assumption validation. In a few isolated instances a log transformation may have been appropriate for better conformation to normality or homogeneity of variances, but we did not use transformations to preserve consistency between the analyses and to avoid back-transforming the least-squares means.

Recruitment rate is the proportion of new snags observed in a year, and is derived from the total number of snags not previously observed. Thus, 1998 was the first year recruitment could be determined because we did not identify snags by the tagging method until 1997. Likewise, loss rate is derived from the number of snags last observed in the previous measurement period relative to the current measurement and, therefore, lost during the interval. Thus, our loss rate ends in 2008 as the last year of observation was 2009.

We used the LIFEREG procedure (SAS Institute Inc. 2004) to fit models to predict snag survival as the number of years until a snag fell. We modeled snag survival separately for pretreatment (snags first observed 1998-2001) and post-treatment (snags first observed 2001.9-2008). The number of years until a snag fell was calculated as the difference between the last year a snag was observed and the year it first appeared. The log of zero is undefined so we did not include snags that were only observed in one year nor did we consider snags initially observed in 2009 (because their last year was indeterminate). The model was developed as a linear function of treatment (CON, DWD, and SWD), initial snag size class (small and large snags), and their interaction, with the dependent variable being the log of number of years until a snag fell. If the treatment $\times$ size interaction was not significant, we removed it from the model. If a snag had not fallen by the end of the study (2009), we classified it as right censored, indicating that the exact
Fig. 1. Diameter distribution for the number of snags per hectare for control (CON), down woody debris (DWD), and standing woody debris (SWD) treatments during pretreatment $(a)$ and post-treatment (b) periods.
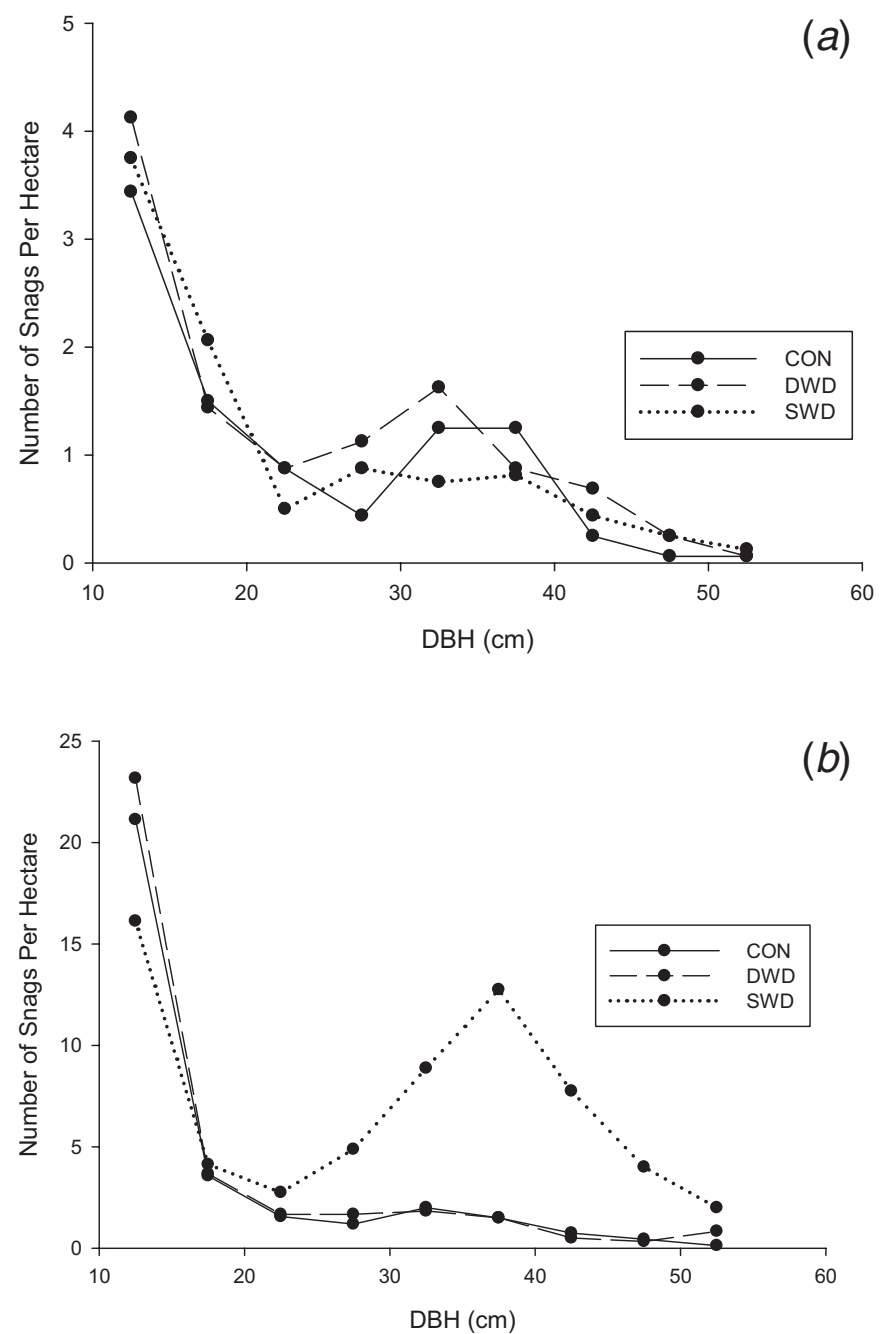

value of the observation (years until the snag falls) was unknown, but the value was at least as large as the observation. Including such censored data in the LIFEREG procedure prevents a bias that would result if it was simply removed from the analysis. We specified the Weibull distribution for the distribution of the dependent variable. For each treatment and size class we obtained the predicted time for $50 \%$ and $90 \%$ of the snags to fall, and we constructed $95 \%$ confidence intervals for the log of time and then transformed back to time. We defined the survival model as

$$
\begin{array}{r}
u=\log (\text { time })=B_{0}+B_{1} \times \text { treatment }+B_{2} \times \text { size } \\
+B_{3} \times \text { treatment } \times \text { size }
\end{array}
$$

where time is the number of years until a snag fell, and $B_{0}, B_{1}, B_{2}$, and $B_{3}$ are estimated parameters. The probability of snag survival to a specified age is then given by

$$
S(\text { age })=\exp \left\{-[\text { age } \times \exp (-u)]^{1 / \text { scale }}\right\}
$$

where scale is an estimated parameter.

The age quantile, where $Q$ is the proportion ( 0 to1) of the snags that have fallen, is calculated as 


$$
\text { age }=\left\{[-\ln (1-Q)]^{\text {scale }}\right\} / \exp (-u)
$$

We monitored cavities in natural snags during the pretreatment and first year post-treatment period. We eliminated data from the SWD treatment in 2001.9 because it contained artificial snags. We used $\chi^{2}$ tests to determine if the proportions of snags with at least one cavity and multiple cavity formation (two or more per snag) were independent of DBH in 1998 and 2001, which were years near the beginning and end of cavity data collection. To assess the effect of snag age on the timing of cavity formation, we calculated the proportion of snags with their first cavity for each cohort for ages 0 through 4 years and the proportion of all snags with at least one cavity for each cohort. The first cavity proportion represents the probability that a snag that had no cavities prior to that age will develop a cavity at that age; that is, it shows the vulnerability of a snag at a given age to first cavity formation. We also assessed whether the bark percentage for snags at the time of initial cavity formation was the same as snags of the same cohort age without cavities using two-sample $t$ tests with equal variances.

\section{Results}

\section{Plot-level responses}

Snag DBH distributions during the pretreatment period were similar among treatments with the majority of snags being in the small size class (Fig. 1a). There were 5.59 small snags.ha ${ }^{-1}(\mathrm{SE}=$ 1.90) and 3.26 large snags $\cdot \mathrm{ha}^{-1}(\mathrm{SE}=0.48)$ during the pretreatment period with corresponding volumes of $0.41 \mathrm{~m}^{3} \cdot \mathrm{ha}^{-1}(\mathrm{SE}=0.15)$ and $2.02 \mathrm{~m}^{3} \cdot \mathrm{ha}^{-1}(\mathrm{SE}=0.27)$. The snag creation treatment in SWD resulted in a shift to more snags in the larger DBH classes compared with the natural distributions in CON and DWD (Fig. 1b).

Few differences were detected among treatments during pretreatment, as expected, since snag manipulation did not occur during this period. There was a significant $(p=0.041)$ treatment $\times$ year interaction for small snag volume, but this variable did not differ significantly among treatments within a given year. Similarly, density of large snags differed among years during pretreatment $(p=0.028)$, with a tendency to increase by 0.55 snags.ha ${ }^{-1}$ over the period 1996 to 2000 (Fig. 2), but the Tukey-Kramer multiple-comparison procedure did not detect any significant differences between years. Thus, removal of down woody debris during the pretreatment period in DWD, which was the only manipulation difference between the treatments, did not affect plot-level snag density or volume.

The SWD treatment increased total snag density 6.7-fold overall and increased large snags 16-fold over the pretreatment baseline average. The average natural and created snag BA in 2001.9 SWD post-treatment plots was $5.2 \mathrm{~m}^{2} \cdot \mathrm{ha}^{-1}$. During the post-treatment period, snag density and volume for small snags had no significant treatment or treatment $\times$ year effects but differed among years (Table 1). Snag density increased abruptly between 2004 and 2005 over all treatments (Fig. 2). In contrast, all treatment, year, and treatment $x$ year effects were significant for large snags during post-treatment (Table 1 ). The snag creation treatment on SWD resulted in a significant treatment $\times$ year interaction owing to increases in density and volume of large snags on SWD relative to CON and DWD from 2003 to 2008 (Table 1 and Fig. 2). The year effect for large snags corresponds to the increase in the snag density and volume on SWD between 2001.9 and 2005-2006, followed by a decline thereafter.

The dynamics during pretreatment (Fig. 2) were characterized by the relative stability of the small and large snag populations across treatments, with low background recruitment and loss rates (0-2 snags.ha ${ }^{-1}$.year ${ }^{-1}$; Fig. 3); this contrasted with the dynamics during post-treatment. From the beginning of posttreatment through 2004 small snags exhibited a slight increase in
Fig. 2. Number of small ( $<25 \mathrm{~cm} \mathrm{DBH})(a)$ and large ( $\geq 25 \mathrm{~cm} \mathrm{DBH})$ (b) size snags per hectare for the control (CON), down woody debris (DWD), and standing woody debris (SWD) treatments during the pretreatment (1996-2001) and post-treatment (2001.9-2009) periods.
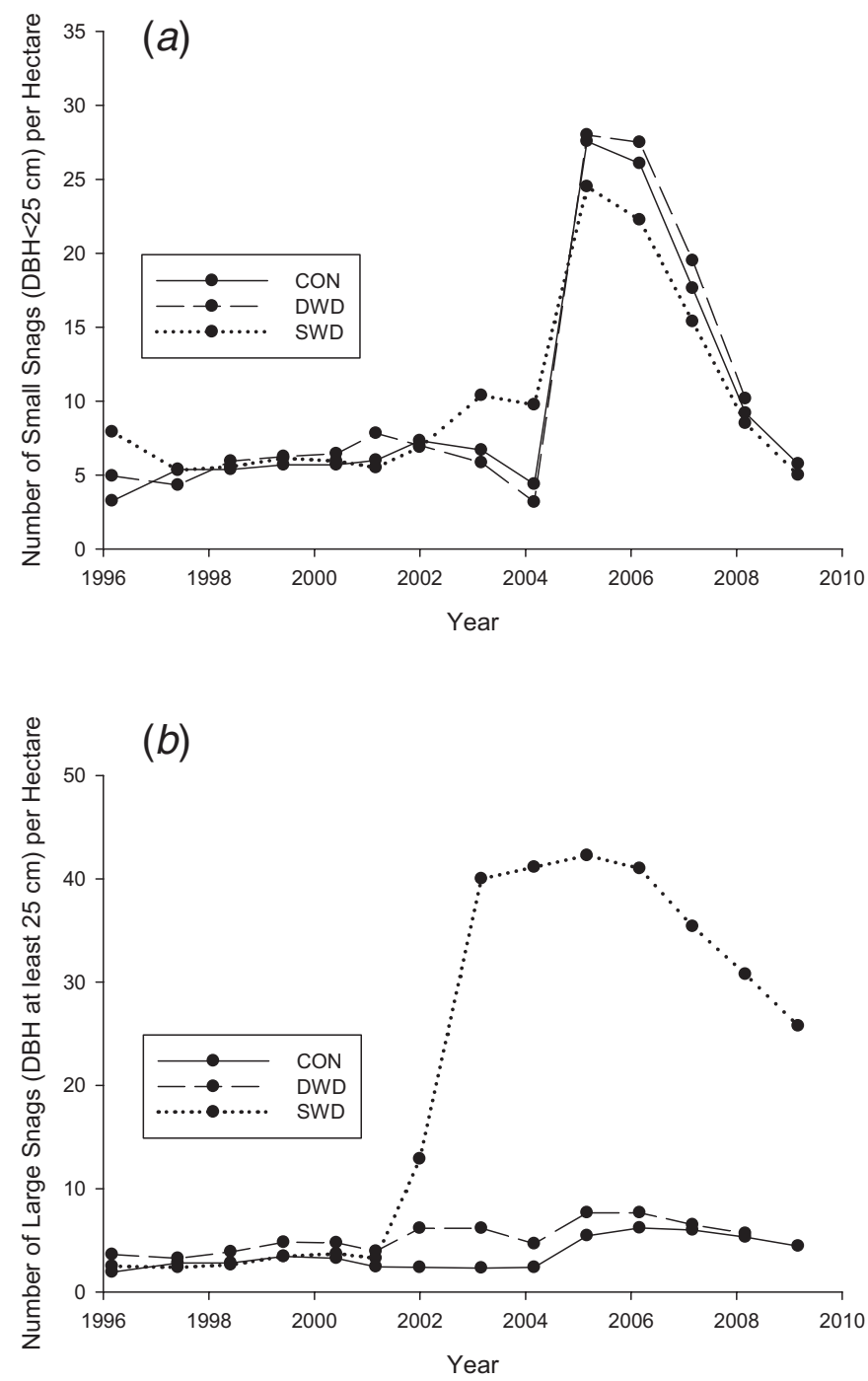

Table 1. Results ( $p$ values) from the analysis on snag density and volume for treatment, year, and their interaction for small $(<25 \mathrm{~cm} \mathrm{DBH})$ and large $(\geq 25 \mathrm{~cm}$ DBH) size snags during the post-treatment period.

\begin{tabular}{lcc}
\hline & $p$ & \\
\cline { 2 - 3 } Source & $\begin{array}{l}\text { Density } \\
\left(\text { snags } \cdot \mathrm{ha}^{-1}\right)\end{array}$ & $\begin{array}{l}\text { Volume } \\
\left(\mathrm{m}^{3} \cdot \mathrm{ha}^{-1}\right)\end{array}$ \\
\hline Small snags & & \\
Treatment & 0.995 & 0.849 \\
Year & $<0.001$ & $<0.001$ \\
Treatment $\times$ year & 0.998 & 0.778 \\
$\begin{array}{l}\text { Large snags } \\
\text { Treatment }\end{array}$ & $<0.001$ & $<0.001$ \\
Year & $<0.001$ & $<0.001$ \\
Treatment $\times$ year & $<0.001$ & $<0.001$ \\
\hline
\end{tabular}


Fig. 3. The rates of recruitment ( $a$ and $b)$, loss $(c$ and $d)$, and net change $(e$ and $f$ ) for small $(<25 \mathrm{~cm} \mathrm{DBH})$ and large $(\geq 25 \mathrm{~cm} \mathrm{DBH})$ size snags, respectively, for the control (CON), down woody debris (DWD), and standing woody debris (SWD) treatments during the pretreatment (1996-2001) and post-treatment (2001.9-2009) periods. Net change is defined as recruitment minus loss.
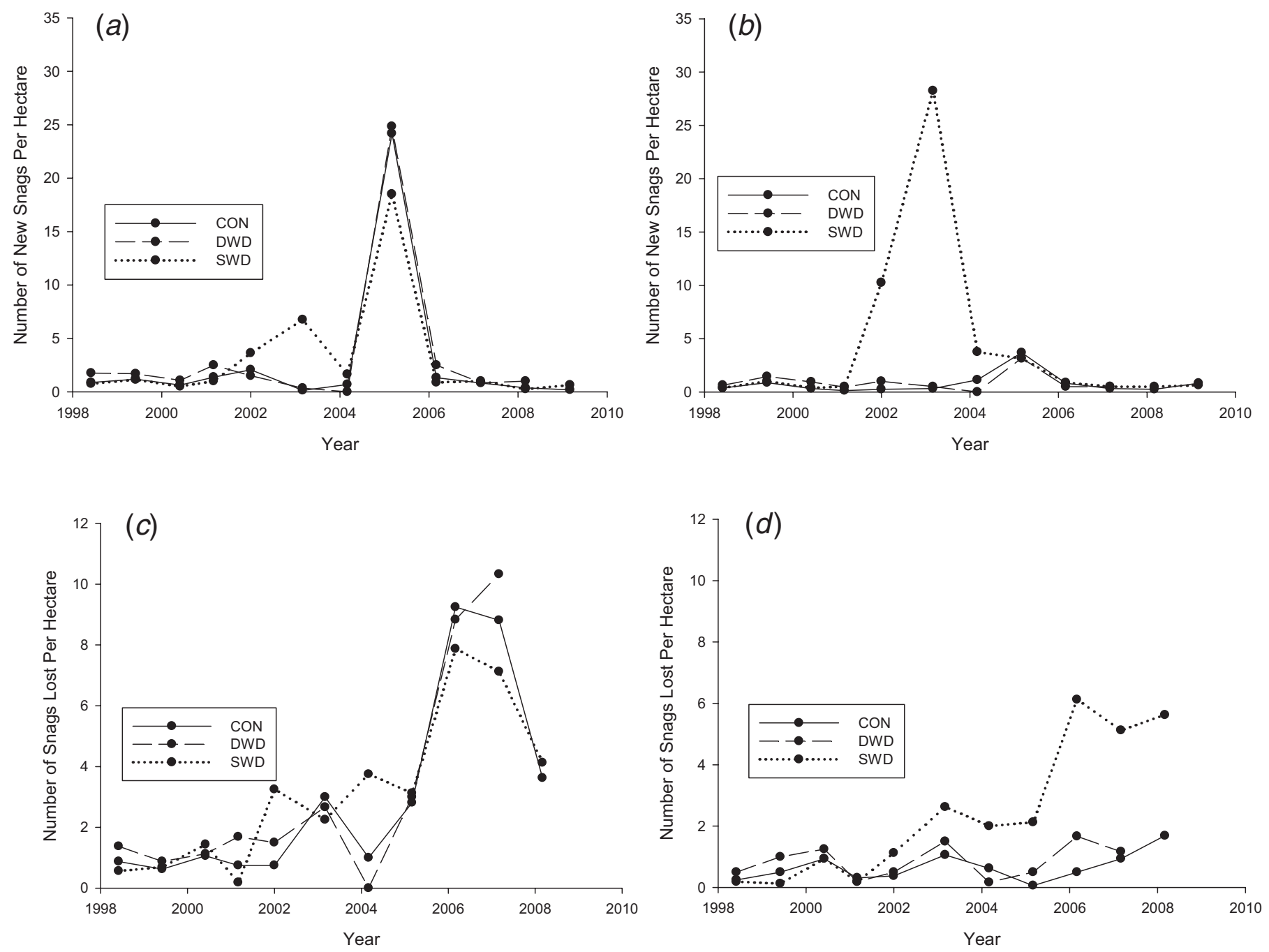

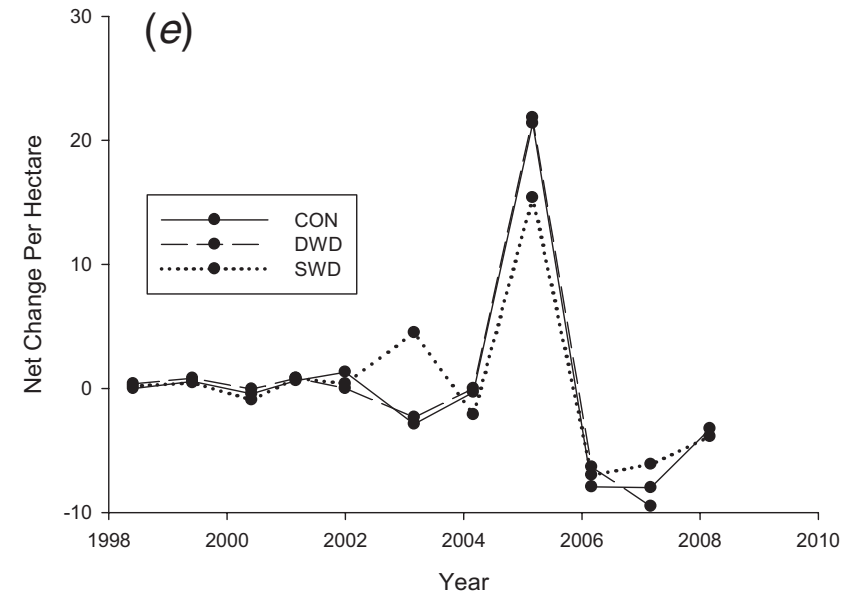

density for SWD, while CON and DWD had a comparable decrease, but large snags exhibited a major increase in the SWD treatment compared with CON and DWD (Fig. 2), which is mainly due to snag creation in the SWD treatment. The large increase in small snags across all treatments in 2005 , accompanied by only a minor in-

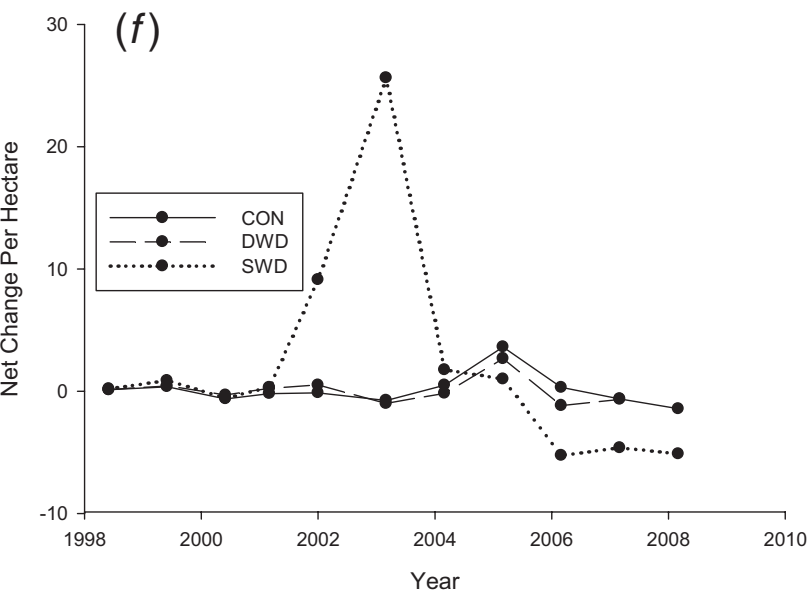

crease in large snags, is likely attributable to a regionwide severe ice storm on 26-27 January 2004 (Aubrey et al. 2007). The smalland large-snag recruitment rates (Fig. 3) differentiate the two high-mortality events during post-treatment; peaks in 2005 for small snags and in 2003 for large snags created by the SWD 
Table 2. The predicted $50 \%$ and $90 \%$ snag-survival time quantiles (years) for the control (CON), down woody debris (DWD), and standing woody debris (SWD) treatments for small $(<25 \mathrm{~cm}$ DBH) and large $(\geq 25 \mathrm{~cm}$ DBH) size snags based on the pretreatment and posttreatment survival models.

\begin{tabular}{|c|c|c|c|c|c|}
\hline \multirow[b]{2}{*}{ Treatment } & \multirow[b]{2}{*}{ Size } & \multicolumn{2}{|c|}{$\begin{array}{l}\text { 50\% Survival } \\
\text { quantile (years) }\end{array}$} & \multicolumn{2}{|c|}{$\begin{array}{l}\text { 90\% Survival } \\
\text { quantile (years) }\end{array}$} \\
\hline & & Estimate & $95 \% \mathrm{CI}$ & Estimate & $95 \%$ CI \\
\hline \multicolumn{6}{|c|}{ Pretreatment (1998-2001) ${ }^{a}$} \\
\hline $\mathrm{CON}$ & SMALL & 2.80 & $2.33-3.37$ & 6.94 & $5.79-8.33$ \\
\hline $\mathrm{CON}$ & LARGE & 3.81 & $3.07-4.73$ & 9.43 & $7.60-11.71$ \\
\hline DWD & SMALL & 1.81 & $1.57-2.09$ & 4.48 & $3.91-5.14$ \\
\hline DWD & LARGE & 2.46 & $2.08-2.91$ & 6.09 & $5.17-7.18$ \\
\hline SWD & SMALL & 1.79 & $1.49-2.15$ & 4.43 & $3.70-5.30$ \\
\hline SWD & LARGE & 2.43 & $1.97-3.00$ & 6.02 & $4.90-7.41$ \\
\hline \multicolumn{6}{|c|}{ Post-treatment (2001.9-2009) } \\
\hline $\mathrm{CON}$ & SMALL & 2.06 & $1.94-2.19$ & 3.95 & $3.72-4.19$ \\
\hline $\mathrm{CON}$ & LARGE & 3.96 & $3.41-4.61$ & 7.59 & $6.49-8.87$ \\
\hline DWD & SMALL & 1.72 & $1.58-1.87$ & 3.29 & $3.02-3.58$ \\
\hline DWD & LARGE & 2.48 & $2.06-2.99$ & 4.75 & $3.95-5.72$ \\
\hline SWD & SMALL & 2.20 & $2.03-2.39$ & 4.21 & $3.89-4.57$ \\
\hline SWD & LARGE & 6.16 & $5.66-6.70$ & 11.79 & $10.74-12.94$ \\
\hline
\end{tabular}

${ }^{a}$ The survival model was $\log ($ time $)=0.8586+0.4487 \times \mathrm{CON}+0.0117 \times \mathrm{DWD}+$ $0.3067 \times$ LARGE, with scale parameter $=0.7556$.

${ }^{b}$ The survival model was $\log ($ time $)=0.9873-0.0651 \times \mathrm{CON}-0.2481 \times \mathrm{DWD}+$ $1.0289 \times$ LARGE $-0.3760 \times$ CON $\times$ LARGE $-0.6604 \times$ DWD $\times$ LARGE, with scale parameter $=0.5409$.

treatment, both of which were followed by sharp declines in recruitment that approached levels observed during the pretreatment period.

\section{Survival analysis}

Both treatment and snag size class explained significant variation in the snag survival models for the pretreatment and posttreatment periods (Table 2). The pretreatment model consisted of treatment $(p<0.0001)$ and size $(p=0.0007)$ and was based on 312 noncensored and 16 right-censored observations. During pretreatment, the model predicted survival age at the 50\% quantile for small snags across the three treatments ranging from 1.8 to 2.8 years and for large snags from 2.4 to 3.8 years. Snag longevity (90\% quantile) during pretreatment was greatest in the CON treatment and in the large snag size class, where most small snags were lost within 4-7 years and large snags within 6-10 years (Table 2). The post-treatment model consisted of treatment $(p<0.0001)$, size $(p<0.0001)$, and treatment $\times$ size $(p<0.0001)$, and was based on 917 noncensored and 344 right-censored observations. As in pretreatment, the post-treatment $50 \%$ quantile for small-snag survival age was lower than for large snags across treatments (Fig. 4), ranging from 1.7 to 2.2 years (Table 2). Longevity (90\% quantile) for large snags was greatest for SWD (11.8 years), followed by CON (7.6 years), and DWD (4.8 years). The SWD natural large snags represented by the pretreatment model did not persist as long as the SWD artificially created large snags, which comprised the majority of the population for the post-treatment model (Table 2).

\section{Cavity dynamics}

The proportion of snags having at least one or two or more cavities was significantly related to DBH class for both survey years 1998 and 2001 (all $\chi^{2}$ tests had $p<0.0001$; Fig. 5). The proportion increased from less than 0.10 in the smallest DBH classes to a maximum of 0.37 and 0.28 for snags forming at least one and two or more cavities, respectively. The trend plateaued between 25 and $40 \mathrm{~cm} \mathrm{DBH}$. The proportion of snags with their first cavities increased with snag age through age 3 years and then declined to zero at age 4 years (Table 3 ). The effect of age on cavity formation is also illustrated by the proportion of snags with at least one
Fig. 4. Modeled probability of snag survival as a function of snag age (years since tree death) for small $(<25 \mathrm{~cm} \mathrm{DBH})(a)$ and large $(\geq 25 \mathrm{~cm}$ DBH) (b) size snags for the control (CON), down woody debris (DWD), and standing woody debris (SWD) treatments during the post-treatment (2001.9-2009) period.
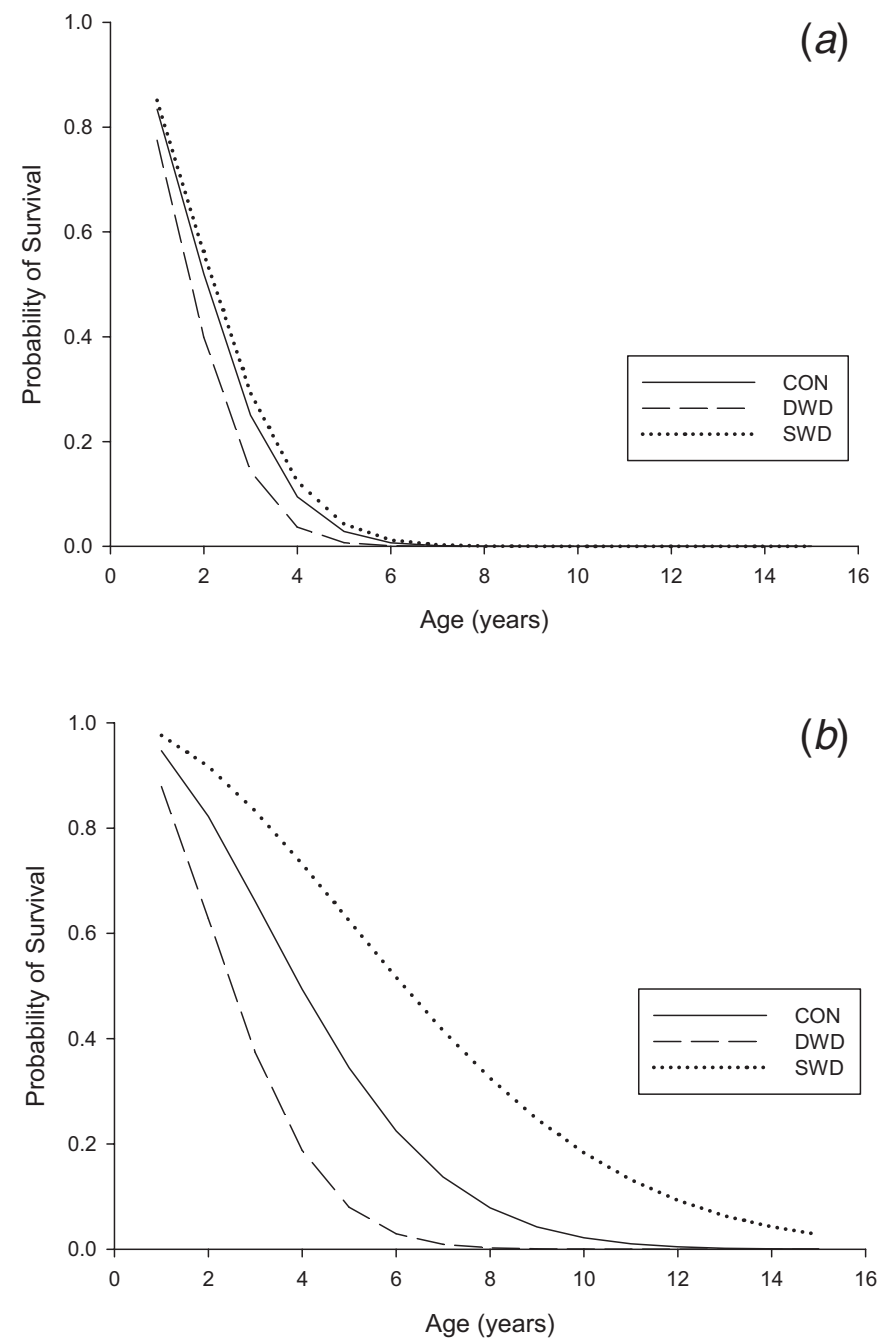

cavity, which increased from 0.02 at age 0 years to 0.22 at age 4 years (Table 3 ). This proportion is higher than the first cavity proportion, since the values represent cumulative cavity formation. The bark percentage for snags at the time of initial cavity formation was about $15 \%$ less than snags of the same age without cavities (Table 3). The two-sample $t$ tests comparing bark percentage between snags with and without initial cavities resulted in significance only for age 2 years $(p=0.0379)$.

\section{Discussion}

We conducted our study in a forest type that dominates the southern USA and in an age class believed to be important for snag-dependent species. Prior to thinning and snag creation, snag densities and volumes were generally similar to those reported from other studies in the region. Our densities were similar to those reported by Moorman et al. (1999) for $>40$-year-old pine plantations in the Upper Piedmont of South Carolina, and were within the broad range reported by Land et al. (1989) for Florida pine plantations. However, our densities were greater than those reported by McComb et al. (1986) for similar-aged pine plantations in Florida and by Homyack et al. (2011) for younger (30- to 35-yearold) plantations in coastal North Carolina. We observed a fairly 
Fig. 5. The proportion of snags within $5 \mathrm{~cm}$ DBH classes that have at least one cavity (a) or at least two cavities (b) in 1998 , and the proportion of snags that have at least one cavity $(c)$ or at least two cavities $(d)$ in 2001 . These years are representative years near the beginning and ending periods of cavity data collection. $\chi^{2}$ tests of diameter class effects are significant in all cases $(p<0.0001)$.
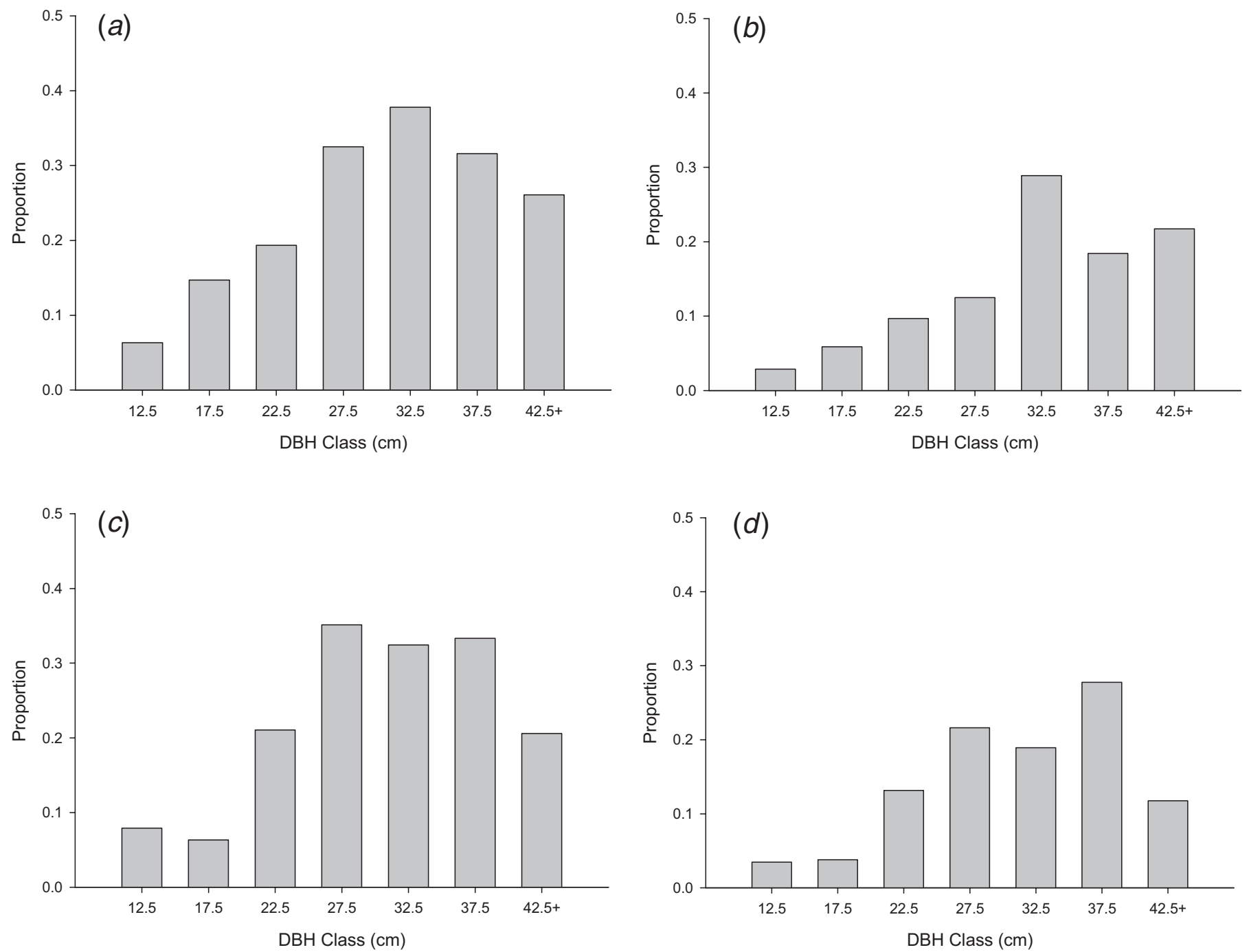

Table 3. Snag cavity distribution and bark percentage for snags with and without cavities.

\begin{tabular}{|c|c|c|c|c|c|}
\hline \multirow[b]{2}{*}{ Snag characteristic } & \multicolumn{5}{|c|}{ Snag age (years) } \\
\hline & 0 & 1 & 2 & 3 & 4 \\
\hline $\begin{array}{l}\text { Proportion of snags with } \\
\text { first cavity }{ }^{a}\end{array}$ & 0.021 & 0.025 & 0.058 & 0.057 & $0.000^{b}$ \\
\hline $\begin{array}{l}\text { Proportion of snags with } \\
\text { at least one cavityc }\end{array}$ & 0.021 & 0.040 & 0.089 & 0.172 & 0.216 \\
\hline $\begin{array}{l}\text { Bark percentage for snags } \\
\text { without cavities }\end{array}$ & 76.5 & 70.0 & 61.9 & 53.9 & - \\
\hline $\begin{array}{l}\text { Bark percentage for snags } \\
\text { at age of first cavity }\end{array}$ & 60.0 & 55.0 & 42.7 & 33.3 & - \\
\hline $\begin{array}{l}{ }^{a} \text { The proportion of snags tha } \\
{ }^{b} \text { No snags formed their first } \\
\text { CThe proportion of snags that } \mathrm{f} \\
{ }^{d} \text { The two-sample } t \text { tests com } \\
\text { without initial cavities resulted } \\
\text { for ages } 0,1,2 \text {, and } 3 \text { years, res }\end{array}$ & $\begin{array}{l}\text { rmed at } \\
\text { aring b }\end{array}$ & $\begin{array}{l}\text { ist one c } \\
\text { percer } \\
\text { of } 0.06\end{array}$ & ge betwe & $\begin{array}{l}\text { he given a } \\
\text { 3 snags obs } \\
\text { n } 1998 \text { and } \\
\text { en snags }\end{array}$ & $\begin{array}{l}\text { ge. } \\
\text { served). } \\
2001.9 . \\
\text { vith and } \\
\text { d } 0.1337\end{array}$ \\
\hline
\end{tabular}

and, occasionally, prescribed fire (Barnard 1999; Sullivan et al. 2003; Outcalt 2008). Moorman et al. (1999) documented similarly low annual recruitment rates and a slight net loss over the measurement interval.

Snag longevity and the factors that control it are important to cavity-dependent species because they determine the duration of suitability for cavity use (Cain 1996). We hypothesized that snag survival would be independent of snag diameter, but we found that survival was affected by snag size, with small snags having a significantly lower survival rate than large snags. This result contrasts with other studies in the region: Moorman et al. (1999) found no such effect across a range of species and forest types, and Radtke et al. (2009) found no DBH effect in pine stands. However, in agreement with our findings, Garber et al. (2005) and Russell et al. (2006) reported that larger snags survived longer in the northern and western forests of North America. The discrepancy among studies may relate to differences in stand structure. For instance, in our plots, small snags existed largely as a postthinning subcanopy layer of pine and hardwood regeneration. Our size-class effect on survival was also confounded with the larger proportion of hardwood small snags (largely oaks). Whatever the cause, small snags in our study did not survive as long as large snags. We also hypothesized that rates of loss would fall within during the pretreatment period. Annual tree mortality rates the region are known to be low for this age class of pines, with primary causes being lightning strikes, root disease, beetle kill, 
the range of previous studies in the region. The age at which $90 \%$ of the snags fell varied from 3.3 to 9.4 years after snag formation for the naturally created snags in CON and DWD, which is within that reported by previous studies in the southern USA (e.g., Cain (1996), Moorman et al. (1999), and Conner and Saenz (2005)), thus reinforcing the influence of high decay rates on snag loss in the region (Eaton and Sanchez 2009) compared with cooler climates (Dunn and Bailey 2012).

Our hypothesis that the treatments would not affect snag survival was rejected. We did not anticipate the greater snag survival in CON than in either DWD or SWD for snags originating during pretreatment and continuing as snags into the post-treatment period. We believe that the application of the treatments may have affected the longevity of these naturally occurring snags observed initially in 1998-2001 because the survival model is based on longevity data over the lifespan of these snags, which includes the post-treatment period. Although existing snags were not intentionally damaged or cut during treatment implementation, mechanical thinning by a feller-buncher in the CON treatment allowed directional control (within strips) of the felling and removal that would minimize damage to residual snags. In contrast, hand felling on the DWD occurred both within and across strips and likely resulted in many more broken tops and knocked over snags by felled stems. Likewise, when created snags in SWD fell, they may have occasionally knocked over some pretreatment snags. This contention is supported by Garber et al. (2005) who reported that the level of disturbance in Maine forests reduced standing snags and by Homyack et al. (2011) who reported the same effects in young pine stands in North Carolina. Russell et al. (2006) found postfire salvage logging resulted in more rapid loss of residual conifer snags in Idaho.

We also found an unexpected significant treatment effect on survival for snags formed during the post-treatment period. Our snag-creation-treatment SWD was designed to simulate a catastrophic level of snag creation leading to high snag densities, but with presumably similar survival rates. The large snag $90 \%$ survival quantiles for artificially created snags was greater than the equivalent for natural snags in the CON and DWD, and nearly twice the value of the natural large snags in the SWD in the pretreatment period. Shea et al. (2002) observed a significantly longer survival period and slower decay in girdled versus beetlekilled Ponderosa pine (Pinus ponderosa Douglas ex P. Lawson \& C. Lawson) snags. Conceivably, natural snags initially have sufficient decay to weaken the stem, which may cause the snag to fall sooner than artificial snags. Our SWD snags were otherwise healthy trees at the time they were treated.

Our hypothesis that the proportion of snags with cavities would increase with snag DBH was confirmed. Cavity proportions for snags with at least one cavity and for two or more cavities increased significantly with DBH. A much higher proportion (five times) of large snags had cavities than did small snags, and large snags also supported more cavities per snag. This result is consistent with the presence of numerous large-bodied excavators in these stands (Lohr et al. 2002). In contrast, our expectation that cavity-formation rates would increase with snag age as a result of increased decay conditions was not confirmed. Cavity excavation increased early in the snag decay process based on the proportion of first cavities in ages $0-3$ years, but no cavity formation was observed in 4-year-old snags. Moorman et al. (1999) reported similar results during the 4-year period following snag formation for loblolly pine and shortleaf pine (Pinus echinata Mill.), but they had a longer data record and observed an increase in cavity frequency among their few remaining pine snags at ages 6 and 7 years $(<5 \%$ of their total snags). Although we found that snags with first cavities had a lower bark percentage than snags without cavities, it is unclear whether this condition is important because the factors determining suitability of snags for various cavity-excavating species are not well understood. To determine whether the avail- ability of suitable snags limits cavity-nesting bird populations in managed mature pine forests of the southeastern Coastal Plain requires direct studies of bird populations themselves, particularly experimental studies (Lohr et al. 2002). Nevertheless, such stands appear to provide more large DBH snags essential to many species than younger managed pine stands in the southeastern USA.

\section{Acknowledgements}

Support for this research was provided by the Department of Energy under Interagency Agreement DE-AI09-00SR22188 and by the USDA Forest Service Southern Research Station. We thank the staff of the US Forest Service Savannah River for their tremendous operations support to implement the study. M. Howard and P. Champlin provided invaluable coordination; and J. Hill, M. Howard, D. Jones, S. Junker, L. Krysinsky, L. Lee, K. Nayda, P. Sharine, F. Spilker, and E. Uramkin assisted with fieldwork. Brett Miley was instrumental in monitoring and maintaining the study during the years from 1998 to 2002 and provided invaluable reports and analysis. We also thank S. Castleberry, J. Davis, M. Dorcas, B. Edwards, W. Ford, J. Hanula, T. Hinkelman, S. Horn, M. Komoroski, S. Loeb, S. Lohr, T. McCay, J. McMinn, K. Mosely, A. Owens, and M. Ulyshen for their contributions as co-investigators.

\section{References}

Aubrey, D.P., Coleman, M.D., and Coyle, D.R. 2007. Ice damage in loblolly pine: understanding the factors that influence susceptibility. For. Sci. 53(5): 580-589.

Barnard, E.L. 1999. Annosum root rot of pines in Florida. Plant Pathology Circular No. 398 (No. 200 revised). Florida Dept. of Agriculture and Consumer Services, Division of Plant Industry, Tallahassee, Fla.

Cain, M.D. 1996. Hardwood snag fragmentation in a pine-oak forest of southeastern Arkansas. Am. Midl. Nat. 136(1): 72-83. doi:10.2307/2426632.

Conner, R.N., and Saenz, D. 2005. The longevity of large pine snags in eastern Texas. Wildl. Soc. Bull. 33(2): 700-705. doi:10.2193/0091-7648(2005)33[700: TLOLPS]2.0.CO;2.

Davis, J.W., Goodwin, G.A., and Ockenfels, R.A. (Technical coordinators). 1983. In Snag habitat management: proceedings of the symposium, Flagstaff, Arizona, 7-9 June 1983. USDA For. Serv. GTR-RM-99.

Dunn, C.J., and Bailey, J.D. 2012. Temporal dynamics and decay of coarse wood in early seral habitats of dry-mixed conifer forests in Oregon's Eastern Cascades. For. Ecol. Manage. 276: 71-81. doi:10.1016/j.foreco.2012.03.013.

Eaton, R.J., and Sanchez, F.G. 2009. Quantitative and qualitative measures of decomposition: Is there a link? South. J. Appl. For. 33(3): 137-141.

Garber, S.M., Brown, J.P., Wilson, D.S., Maguire, D.A., and Heath, L.S. 2005. Snag longevity under alternative silvicultural regimes in mixed-species forests of central Maine. Can. J. For. Res. 35(4): 787-796. doi:10.1139/x05-021

Hagar, J.C., McComb, W.C., and Emmingham, W.H. 1996. Bird communities in commercially thinned and unthinned Douglas-fir stands of western Oregon. Wildl. Soc. Bull. 24: 353-366.

Homyack, J.A., Paxton, B.J., Wilson, M.D., Watts, B.D., and Miller, D.A. 2011. Snags and cavity-nesting birds within intensively managed pine stands in eastern North Carolina, U.S.A. South. J. Appl. For. 35(3): 148-154.

Kilgo, J.C., and Blake, J.I. (Editors). 2005. Ecology and management of a forested landscape: fifty years on the Savannah River Site. Island Press, Covelo, Calif.

Land, D., Marion, W.R., and O'Meara, T.E. 1989. Snag availability and cavitynesting birds in slash pine plantations. J. Wildl. Manage. 53(4): 1165-1171. doi: $10.2307 / 3809628$.

Littell, R.C., Milliken, G.A., Stroup, W.W., Wolfinger, R.D., and Schabenberger, O. 2006. SAS for mixed models. 2nd ed. SAS Institute Inc., Cary, N.C.

Lohr, S.M., Gauthreaux, S.A., and Kilgo, J.C. 2002. Importance of coarse woody debris to avian communities in loblolly pine forests. Conserv. Biol. 16(3): 767-777. doi:10.1046/j.1523-1739.2002.01019.x.

McCay, T.S., Hanula, J.L., Loeb, S.C., Lohr, S.M., McMinn, J.W., and Wright-Miley, B.D. 2002. The role of coarse woody debris in southeastern pine forests: preliminary results from a large-scale experiment. In Proceedings of the symposium on the ecology and management of dead wood in western forests, Reno, NV, 2-4 November 1999. W.F. Laudenslayer, Jr., P.J. Shea, B.E. Valentine, C.P. Weatherspoon, and T.E. Lisle (Technical Coordinators). USDA For. Serv. Gen. Tech. Rep. PSW-GTR-181. pp. 135-144.

McComb, W.C., Bonney, S.A., Sheffield, R.M., and Cost, N.D. 1986. Snag resources in Florida - Are they sufficient for average populations of primary cavity nesters? Wildl. Soc. Bull. 14: 40-48.

McMinn, J.W., and Crossley, D.A., Jr. (Editors). 1996. Biodiversity and Coarse Woody Debris in Southern Forests. Proceedings of the Workshop on Coarse Woody Debris in Southern Forests: Effects on Biodiversity, Athens, Georgia, 18-20 October 1993. USDA For. Serv. Gen. Tech. Rep. SE-94.

Moorman, C.E., Russell, K.R., Sabin, G.R., and Guynn, D.C., Jr. 1999. Snag dynam- 
ics and cavity occurrence in the South Carolina piedmont. For. Ecol. Manage. 118: 37-48. doi:10.1016/S0378-1127(98)00482-4

Ohmann, J.L., McComb, W.C., and Zumrawi, A.A. 1994. Snag abundance for primary cavity nesting birds on nonfederal forest lands in Oregon and Washington. Wildl. Soc. Bull. 22: 607-620.

Outcalt, K.W. 2008. Lightening, fire and longleaf pine: using natural disturbance to guide management. For. Ecol. Manage. 255: 3351-3359. doi:10.1016/j.foreco. 2008.02.016.

Radtke, P.J., Amateis, R.L., Prisley, S.P., Copenheaver, C.A., Chojnacky, D.C., Pittman, J.R., and Burkhart, H.E. 2009. Modeling production and decay of coarse woody debris in loblolly pine plantations. For. Ecol. Manage. 257: 790-799. doi:10.1016/j.foreco.2008.10.001.

Rosenberg, D.K., Fraser, J.D., and Stauffer, D.F. 1988. Use and characteristics of snags in young and old forest stands in Southwest Virginia. For. Sci. 34: 224-228.

Russell, R.E., Saab, V.A., Dudley, J.G., and Rotella, J.J. 2006. Snag longevity in relation to wildfire and postfire salvage logging. For. Ecol. Manage. 232: 179-187. doi:10.1016/j.foreco.2006.05.068.
Sabin, G.R. 1991. Snag dynamics and utilization by wildlife in the upper Piedmont of South Carolina. M.Sc. thesis, Clemson University, Clemson, S.C. p. 49.

SAS Institute Inc. 2004. SAS/STAT 9.1 user's guide. SAS Institute Inc., Cary, N.C. Shea, P.J., Laudenslayer, W.F., Jr., Ferrell, G., and Borys, R. 2002. Girdled Versus Bark Beetle-Created Ponderosa Pine Snags: Utilization by Cavity-Dependent Species and Differences in Decay Rate and Insect Diversity. In Proceedings of the Symposium on the Ecology and Management of Dead Wood in Western Forests, Reno, Nevada, 2-4 November 1999. William F. Laudenslayer, Jr., Patrick J. Shea, Bradley E. Valentine, C. Phillip Weatherspoon, and Thomas E. Lisle (Technical Coordinators). USDA For. Serv. Gen. Tech. Rep. PSWGTR-181. pp. 145-153.

Sullivan, B.T., Fettig, C.J., Otrosina, W.J., Dalusky, M.J., and Berisford, C.W. 2003. Association between severity of prescribed burns and subsequent activity of conifer-infesting beetles in stands of longleaf pine. For. Ecol. Manage. 185: 327-340. doi:10.1016/S0378-1127(03)00223-8.

Wiebe, K.L. 2011. Nest sites as limiting resources for cavity-nesting birds in mature forest ecosystems: a review of the evidence. J. Field Ornithology, 82(3): 239-248. doi:10.1111/j.1557-9263.2011.00327.x. 